\title{
Exploring the Consumer Co-Operative Relationship with Their Members: An Individual Psychological Perspective on Ownership
}

\author{
Dr. Saroj Kumar Singh ${ }^{1 *}$
}

\section{ABSTRACT}

It is argued in co-operative literature that a distinctive feature of consumer co-operatives is the strong linkage between customers and their co-operative organization. Another distinctive feature identified is the nature of ownership. Bridging these two is the claim that is the nature of ownership that creates the special bond between customers and their cooperatives. In this theoretical paper, we elaborate this idea further, employing a psychological ownership perspective. Limiting our work on the individual-level, we analyze co-operative literature through the definition of psychological ownership, development mechanisms, and underlying motives showing that the feelings of ownership can be an essential part of being a member. Our concluding remarks are for the attention of both researchers and practitioners.

Keywords: Consumer Co-operatives, User-ownership, Psychological Ownership

Many co-operative scholars (e.g., Normark, 1996; Giroux, 1992) have argued that the association of the roles of customer and owner promote the development of an intimate relationship between the customer and the co-operative a special 'co-operative link.' That is, "The co-operative form of organization has the potential to develop unusually strong linkages between the user and the focal enterprise” (Normark, 1996: 433). This link has the potential to develop under conditions of ownership that is not speculative nature, but associational instead (i.e., one that produces benefits through use and includes an equal voice in governance; cf. Hansmann, 1996; Bager, 1994). As Giroux (1992) maintains: "It is indeed the special memberuser status of owners that constitutes the co-operatives specific nature” (p. 7). Evidently, the special relationship between the customer and the cooperative is seen a source of psychological rewards for the member and, thus as a source of competitive advantage (e.g., Jussila, Tuominen, \& Saksa, 2008). Less evident are the meanings of 'strong linkage' and the mechanisms through which member association with the co-operative contributes to it. Giroux (1992), though, notes, "participation appears essential because it sustains the relations of meaning, use, and property

\footnotetext{
${ }^{1}$ Associate Professor, Department of Rural Economics, S. N. S. R. K. S. College, Saharsa, India

*Responding Author

Received: January 9, 2017; Revision Received: February 3, 2017; Accepted: February 7, 2017

(C) 2017 Singh S; licensee IJIP. This is an Open Access Research distributed under the terms of the Creative Commons Attribution License (www.creativecommons.org/licenses/by/2.0), which permits unrestricted use, distribution, and reproduction in any Medium, provided the original work is properly cited.
} 


\section{Exploring the Consumer Co-Operative Relationship with Their Members: An Individual Psychological Perspective on Ownership}

that form the co-operative link" (p. 24). We also know that the special bond between the members and their co-operatives result from the fact that members are able to influence the cooperative both in their role as a user and as an owner (Hirschman 1979).

In addition, the work of Normark (1996) speaks to the importance of knowledge in creating the link. Finally, Giroux (1992) also argues that: "In the co-operative, members pool their aspirations, their needs, and their resources to produce relations based on meaning, use, and property which link the associated members and the enterprise they have created.” (p. 7). In other words, the variety of ways members invest themselves into the co-operative is seen to contribute to the emergence of the 'co-operative link.'

\section{Lacking a Coherent Framework}

So far, it seems that there is no co-operative literature that brings the above notions under a coherent framework. A line of research has emerged that offers us the possibility to do that. To be more precise, as an outgrowth of scholarship (e.g., Klein, 1987; Long, 1979, 1980; Rousseau \& Shperling, 2003; Tannenbaum, 1983) that addresses the role of formal ownership arrangements (e.g., ESOPs) in the attempts to create more intimate ties between employees and their employers, literature (e.g., Brown, 1989; Dirks, Cummings \& Pierce, 1996; Pierce et al., 1991; Pierce et al., 2001; Pierce \&Furo, 1990; Pierce, Kostova, \& Dirks, 2003; Pierce, O’Driscoll, \& Coghlan, 2004; Pierce \& Rodgers, 2004; VandeWalle et al., 1995; Van Dyne \& Pierce, 2004; Wagner, Parker, \& Christiansen, 2003) has emerged that addresses the role of psychological ownership in creating a stronger link between organizational members and their organizations. Psychological ownership is that cognitive/affective state in which the individual feels as though the target of the ownership, or a piece of it, is "hers" or "his" and in which the individual feels as though s/he is psychologically tied to that object, the extended self (Pierce et al., 2001). In this literature, property is recognized to exist on both objective and subjective levels (Etzioni, 1991), and the targets of ownership are seen to be of both tangible and intangible nature (e.g., Beaglehole, 1932; Isaacs, 1933). Most influential developers of psychological ownership theory have been Pierce and his colleagues (e.g., Pierce, Rubenfeld, \& Morgan, 1991; Pierce, Kostova, \& Dirks, 2001, 2003; Van Dyne \& Pierce, 2004). They maintain that - as a state of mind - psychological ownership (e.g., the possessive feeling that some organizational object is 'MINE') may develop even in the absence of legal ownership. Considering the audience of this journal, perhaps their most important notion is that the psychological experience of possession is likely to be promoted by formal ownership if it is participatory in nature (e.g., if it encourages personal investments and provides the members with control and knowledge).

While psychological ownership has not been studied in co-operatives with a particular focus on user ownership, several studies do refer to co-operatives as organizations in which psychological ownership is likely to manifest it. That is, Pierce et al. (1991) and Pierce and Rodgers (2004), in 


\section{Exploring the Consumer Co-Operative Relationship with Their Members: An Individual Psychological Perspective on Ownership}

their discussion of employee ownership arrangements, refer to (worker) co-operatives as a potential target of ownership feelings (e.g., “This is MY co-operative!”). In addition, at least one empirical study also uses data from co-operatives. In their study on ownership feelings and commitment, Vandewalle et al. (2005) gathered a sample from residents of a co-operative housing arrangement at the University of Minnesota- Minneapolis. Finally, Jussila, Saksa, and Tienari (2007) as well as Tuominen, Jussila, and Saksa (2006) use psychological ownership as part of their frameworks employed to analyze management and governance of customer-owned co-operation. In other words, there already exists some literature published in English that contributes to co-operative researchers' understanding of the psychological aspects of cooperative ownership. However, extant co-operative literature does not use the theory of psychological ownership to conduct a detailed analysis of the routes through which this psychological state develops or the origins of that state. It is towards that end this paper is directed.

\section{LINKING PSYCHOLOGY OF OWNERSHIP TO COOPERATIVE MEMBERSHIP}

The innovative approach in our paper is in the following. First, we take the opportunity to define the special co-operative link between the members and their co-operatives as the operational cognitive/affective state of psychological ownership (cf. Van Dyne \& Pierce, 2004). This provides us with possibilities for future empirical research investigating that relationship. Second, we explore some of the mechanisms through which psychological ownership emerges. This serves the management of member-cooperative- relationships: the reinforcement of the cooperative link. Third, we introduce the motivational underpinnings of the 'co-operative link' from the psychology of possessions perspective. This contributes to our understanding of the reasons for member participation that go beyond commonly highlighted economic motivations. A detailed discussion of the whole variety of consequences (attitudinal, behavioral and motivational) that are seen as an out-growth of psychological ownership (see Pierce, Jussila, \& Cummings, 2009), is not feasible in this paper and, thus, is left for future considerations.

In this paper we limit our brief analysis to the satisfaction members get via the fulfillment of their motives for possession in the co-operative organization. This brings us to our forth contribution, which is the identification of previously unspecified satisfactions a consumer cooperative can bring to a member's life. Finally, we note that many of these factors may be applicable to other co-operative contexts. However, we limit our discussion to consumer cooperatives for a clear purpose. We believe it crucial to the development of co-operative research that different types of co-operatives are discussed separately, unless comparisons across them are an explicit aim of research. In this paper, that is not the case.

Our paper is structured as follows. First, we briefly introduce the reader to the background of psychological ownership research and to the origins of those definitions that are the basis of our 


\section{Exploring the Consumer Co-Operative Relationship with Their Members: An Individual Psychological Perspective on Ownership}

work. Second, we discuss the motives for psychological ownership, specifying also related satisfactions. Third, we explore the routes through which this psychological state emerges. Finally, after summarizing our discussion, we put forward a number of conclusions that we believe to be of value to future research on co-operatives.

\section{Psychological Ownership in Organizations}

The theory of psychological ownership (Pierce et al., 2001, 2003) has its roots in a wide variety of fields. Various aspects of ownership have been topics of academic discussion in the realms of psychology, philosophy, human development, social psychology, and consumer behavior, for example. Long ago, James (1890), addressed psychological perspectives on ownership in his work on the principles of psychology, and Sartre (1969) wrote of ownership as an integral part of human existence. Isaacs (1933) and Furby (1978a, b, 1980) illustrated the role of possessions in human social development. Furby (1978b), in her empirical work on meaning and motivation of human possessions, states that possession is ubiquitous in our everyday lives. Beagle hole (1932), studying the psychological basis of the institution of property, found a wide variety of objects in human life that the human could call her/his property. Legally we may be owners of certain physical objects, but it is also common for people to psychologically experience the connection between themselves and various targets of possession, such as homes, automobiles and other people (Dittmar, 1992). We may also develop feelings of ownership toward nonphysical entities, such as ideas, artistic creations and privileges (Beaglehole, 1932; Isaacs, 1933; Heider, 1958).

Some scholars have emphasized the fact that we tend to perceive certain objects as closely related to ourselves (Prelinger, 1959). For example, James comments on the fine line between "me” and "mine”: “A man's self is the sum total of all that he can call his" (1890: 291). Sartre observed that "the totality of my possessions reflects the totality of my being...I am what I have...What is mine is myself” (Sartre, 1969: 591-592). Some others (e.g., Belk, 1988; Dittmar, 1992; Furby, 1978b) have argued that individuals regard possessions as part of the self (identity): “what is mine becomes (in my feelings) part of ME” (Isaacs, 1933: 225). Thus, it is argued that often possessions come to play such a dominant role in the owner's identity that they become part of the 'extended self' (e.g., Belk, 1988; Cram \& Paton, 1993; Dittmar, 1992). This is based on the above philosophically and empirically anchored literature that Pierce et al. (2001) developed in their definition of psychological ownership. They maintain that the core of psychological ownership is constructed of two intertwined feelings: 1) the feeling of possessiveness (i.e., "It is mine!”), and 2) the feeling of being psychologically tied to an object, the extended self (i.e., "It is part of me") - feelings that are part of the human condition. This definition is also the foundation of our work. Extant literature with references to or data from a co-operative context (e.g., Jussila et al., 2007; Tuominen et al., 2006; Pierce \& Rodgers, 2004; 


\section{Exploring the Consumer Co-Operative Relationship with Their Members: An Individual Psychological Perspective on Ownership}

VandeWalle et al., 1995; Pierce et al., 1991) has already addressed the fact that psychological ownership manifests itself also (if not even in particular) in cooperatives.

As declared in the data of Tuominen et al. (2006: 15), "essential is ... that the members of the regional co-operative retailer feel that it is their own firm."Thus, we will simply point out that a sense of ownership manifested by statements such as "I feel this co-operative is MINE", "I feel a high degree of personal ownership for this co-operative." and "I sense this co-operative is part of me” are likely to be put forward by members of consumer co-operatives. In our view, these statements are indicative of the special co-operative link between the members and their cooperative organizations referred to by Normark (1996) and Giroux (1992) among others. Considering future research, it is noteworthy that Van Dyne and Pierce (2004) have offered a valid individual-level operationalization of psychological ownership along with measurement variables.

Why should the above statements be considered as indicative of the co-operative link? This is because that link is seen because of member co-operative interaction that involves the control of members over the co-operative, their intimate knowledge and understanding of the co-operative, and their investments into the co-operative project (e.g., Normark, 1996; Giroux, 1992; Hirchman, 1979).According to Pierce and his colleagues (2001), these are precisely the mechanisms though which the psychological state of ownership develops.

\section{Routes to Psychological Ownership}

According to Pierce et al. (2001), psychological ownership emerges through three major, potentially interrelated routes: 1) control over the target, 2) intimate knowledge of the target, and 3) investment of the self into the target. As introduced, formal ownership of an organization has the potential of promoting the emergence of ownership feelings (Pierce \& Rodgers, 2004; Pierce et al., 1991). This will be the case if formal ownership helps the individual travel down one or more of the above-mentioned routes to psychological ownership. As the above discussion entails and the following discussion shows, the nature of co-operative consumer-ownership meets these conditions.

\section{Control}

The right to use an object and/or to exercise control over it have been among the most frequently mentioned characteristics of possession and ownership (Furby, 1978a; Rudmin\& Berry, 1987). According to literature on co-operatives (e.g., Hansmann, 1996), these rights are also in the core of co-operative ownership. Moreover, it is argued that members are able to influence the cooperative both in their role as a user and as an owner (Hirschman 1979). As maintained by Tuominen et al. (2009), members may exercise control over their co-operative directly and/or indirectly, through market and/or voice mechanisms (cf. Chaves et al., 2008; Spear, 2004).

(C) The International Journal of Indian Psychology, ISSN 2348-5396 (e)| ISSN: 2349-3429 (p) | 126 


\section{Exploring the Consumer Co-Operative Relationship with Their Members: An Individual Psychological Perspective on Ownership}

Most interesting considering the aims of this paper is that control exercised over an object eventually gives rise to feelings of ownership, as shown in research on the psychology of possession (e.g., Csikszentmihalyi \& Rochberg-Halton, 1981; White, 1959). Further, it is argued that the greater the amount of control, the more the object is experienced as part of the self (Furby, 1978a; Prelinger, 1959). Thus, it can be argued that co-operative members may also to develop feelings of ownership towards the co-operative (i.e., come to the subjective experience of the co-operative as 'theirs' and as part of the extended self). Pierce et al. (2001) note that in general, organizations "provide members with numerous opportunities to exercise varying degrees of control over a number of factors, each of which is a potential target of psychological ownership” (p. 301). However, whether or not this actually takes place (and to what extent) is a matter of personal choice (to what extent a member uses one's opportunities to exercise control). In consumer co-operatives, one may choose to simply use the services without the use of voice, while others sit in customer committees and boards. As Giroux (1992) put it: "In co-operatives, the associated members collectively delegate their power as owners to elected representatives, while, most often, exercising their rights as users on an individual basis” (p. 6). Thus, some members may take the route of control towards feelings of ownership towards the co-operative, while others will not.

\section{Self-investment}

The relationship between personal investment and ownership was a popular discussion topic during the industrialization period. Locke (1690), for example, in giving his views on property and government stated that work and labor were ways for people to become (individual) owners of (common) property. This can be applied to co-operatives as well, where the cooperative is in fact, as Jussila et al. (2008) maintain, to great extent a collective possession. As Giroux (1992) put it: "Participation ... allows members to contribute to the co-operative ("to do their share")" (p. 6). The target of contribution is not the share ('possession') of just any member, but that of a particular individual. Locke's (1690) notion was based on the following argumentation: we own our labor (that to which we direct our bodies), we associate our labor with the resulting products or creatures, and therefore we own that which we create, shape, or produce. Most important considering our efforts is the psychological explanation offered by Csikszentmihalyi and Rochberg-Halton (1981). They suggest that the investment of an individual's energy, time, effort, and attention in objects causes her or him to become one with the object and to develop feelings of ownership toward it. Investment of the self comes in many forms: of one's time, ideas, skills, and physical, psychological, and intellectual energies. Because of personal investment, the individual may begin to feel that the target of ownership flows from the self. Thus, as Pierce et al. (2001) argue, the more individuals invest themselves in a target, the stronger their psychological ownership of that target will be. The work of Giroux (1992) seems to be consistent with these ideas. In other words, her work suggests that the variety of ways members invest themselves (personal resources) into the co-operative (creation) contributes to 


\section{Exploring the Consumer Co-Operative Relationship with Their Members: An Individual Psychological Perspective on Ownership}

the emergence of the 'co-operative link.' Organizations provide a wealth of opportunities for their members to invest themselves in a variety of facets. This applies to co-operatives as well. To benefit from the co-operative, it is not sufficient that a member pays the co-operative (financial) contribution.

One has to invest also one's time, energy and physical resources to the use of services. The amount of investment is seen to differ from that of the investments made by regular customers to non-cooperative firms. For example, as a result of the combined roles of customer and owners, the member will be "more willing to provide higher quality, more frequent, and greater amounts of information than would a customer...of an IOF" (Cook, 1994: 53).

Overall, the member has an interest to invest oneself in the co-operative in order to get more benefits (Jussila et al., 2008). Just as proposed concerning control and knowledge, it is likely that there are great differences between members in the amount of their investment (of their selves) to their co-operatives. It can be assumed that the most passive members simply invest the minimum time and energy required to manage their purchases. According to Giroux (1992), the most active ones make considerable investments into the co-operatives, for example, in terms of time and communication.

Thus, there are members who invest a great deal of themselves to their co-operatives and, thus, travel far and deep to the feelings of ownership, while others do not. Having discussed the routes to psychological ownership (i.e., direct causes for its occurrence), an important question asks: Why do some members take these routes? (i.e., what are the primary reasons for ownership feelings?).

\section{Motives for Psychological Ownership}

Pierce and colleagues (2001) note that some scholars explain the emergence of psychological ownership as the innate human need to possess (e.g., Burk, 1900; Porteus, 1976; Weil, 1952), while others suggest that ownership and its psychological state is the product of socialization practices carried out in society (e.g., Furby, 1978b; Kline \& France, 1899). According to Dittmar(1992), both genetic factors and experiences are important: "psychological ownership emerges because it satisfies certain human motives, some of them genetic and others social in nature” (Pierce et al., 2001: 300). Pierce et al. (2001, 2003) suggest that the roots of psychological ownership are to be found in four basic human motives: 1) efficacy and effectance, 2) self-identity, 3) "having a place," and 4) stimulation. As the following discussion shows, existing co-operative literature seems to carry the idea that these motives can be satisfied in co-operatives.

(C) The International Journal of Indian Psychology, ISSN 2348-5396 (e)| ISSN: 2349-3429 (p) | 128 


\section{Exploring the Consumer Co-Operative Relationship with Their Members: An Individual Psychological Perspective on Ownership}

\section{Efficacy and Effectance}

Effectance motivation aims for the feeling of efficacy (White, 1959). Several authors, including Furby (1978a), Isaacs (1933) and Porteus (1976), have recognized that the motive underlying possession is, by and large, the individual's ability to produce effects in the environment - to experience causal efficacy and control. In her cross-cultural studies, Furby (1978b) found empirical evidence supporting these notions, since the desire for control was cited frequently as a motivation for ownership. Possessions provide control for their holder, and ownership allows individuals to explore and alter their environment: thus possessions and ownership serve effectance and competence motives. Beggan (1991) continued on the theme by empirically demonstrating the link between motivation for control and possessive behavior.

Co-operative literature (e.g., Münkner, 1981; Normark, 1996; Nilsson, 1996; CasadesusMasanell \& Khanna, 2003) leads us to believe that members' need to manage their lives (both economic and social aspects of it) is and has been a central impetus also for facilitating (and possession of) co-operative organizations. For example Münkner (1981) states that an individual (i.e., member) engages in voluntary association with others to meet her/his needs - through selfhelp action, a member overcomes one's own weaknesses. By collaborating and networking in the form of co-operative, individual's ability to produce effects in the environment increases (Normark, 1996).

Thus, the co-operative is one of those objects in the members' lives that can promote their feelings of efficacy and effectance. As Pierce et al. (2001) note, the desire to experience causal efficacy in altering the environment leads to attempts to take possession (to exercise control) and, thus, to the emergence of ownership feelings (Pierce et al., 2001). As previously discussed, control can be exercised in many forms, in different roles, and towards a variety of targets. Whether or not the individual will exercise control over the co-operative depends on the extent to which the member's need for efficacy and effectance is active.

\section{Self-identity}

Objects constitute a system of socially shared symbols, particularly symbols of identity, which means that possessions - material or immaterial - also serve certain symbolic functions that are interpreted through one's culture (Dittmar, 1992). According to Porteus (1976), possessions such as the ones we use to personalize our homes help us to determine ourselves (to answer the question: "Who am I?") - “The thingsthat surround us are inseparable from which we are” (Csikszentmihalyi \& Rochberg-Halton, 1981: 16).

Possessions also play an important role in maintaining the sense of self over time (Cram \& Paton, 1993). As Pierce et al. (2001) summarize, people use ownership for the purpose of defining themselves, expressing their self-identity to others, and ensuring the continuity of the 


\section{Exploring the Consumer Co-Operative Relationship with Their Members: An Individual Psychological Perspective on Ownership}

self over time.In literature on co-operatives (e.g., Münkner, 1981; MacPherson, 1995; Nilsson, 1996), it is maintained that membership in a co-operative helps an individual reproduce and express one’s self-identity (e.g., an image that “I am a co-operator”). That is, members build up their roles though the association with cooperatives and through the contributions, they make to the co-operative as customers (Münkner, 1981). The co-operative resulting from collective action of members, manifest the values and goals of those members. Note-worthy, the principle of political and religious neutrality promotes the idea that members participate as individuals, not as representatives of some political or religious interest group (cf. Münkner, 1981; MacPherson, 1995).

Thus, the co-operative is an object that has the potential of satisfying the members' needs for selfidentity. As Dittmar (1992) and Porteus (1976) argue, through our interaction with possessions, coupled with a reflection upon their meaning, we may also reproduce and transform our self-identity and expressour individuality (Dittmar, 1992; Porteus, 1976). As earlier discussion suggests, the interaction and association (coming to know) can occur in many forms, in different roles, and with many objects of material or immaterial nature. Whether or not the individual will exercise control over the co-operative depends on the extent to which the member's need for self-identity is active.

\section{Having a Place}

Ownership and the associated psychological state can also be explained (in part) in terms of the individual's motive to possess a certain territory or space (Ardrey 1966; Duncan, 1981; Porteus, 1976; Weil, 1952). Ardrey (1966) suggests that our attachment to property, such as territory, is of an ancient biological order: having a place is an important "need of the human soul" (Weil 1952: 41). Heidegger (quoted in Dreyfus, 1991: 44-45) argues that we need objects in order to be as we are "When we inhabit something, it is no longer an object to us, but becomes a part of us and pervades our relation to other objects in the world."According to Duncan (1981), who writes of various aspects of home ownership, satisfying the motive of having a place is closely related to satisfying the motives of self-identity and effectance: "The ideal home environment is a place for self-expression and a feeling of control” (p. 113).

The work of Tuominen et al. (2006), on regionalist and locality in management of customerowned cooperatives, provides us with initial understanding on the role of consumer co-operatives as the satisfiers of territorial motives. It describes co-operatives, such as co-operative retailers and co-operative banks, as organizations with two important features: 1) clear geographic boundaries and 2) permanent embeddedness within the region or locale they operate. While not clearly stated in the work of Tuominen and colleagues (2006), it seems that these features are seen to help consumer co-operatives - the member's own organizations - make their members 


\section{Exploring the Consumer Co-Operative Relationship with Their Members: An Individual Psychological Perspective on Ownership}

feel at home. In other words, consumer co-operative can offer a member with placement and understanding of him/herself in the time and space.

Thus, it is within the co-operative that members find place and home - be successful infusing oneself in time and space, and developing a sense that one is 'within'" and a "part of "' some particular place. As Pierce et al. (2009) suggest, this state reflects the discovery of personal meaning and comfort in time and space. It is in this context that psychological ownership develops through interaction with one's surrounding (i.e., through the mechanisms listed above). As earlier discussion indicates, this interaction with the co-operative may occur in various forms, in many roles, and include a variety of different targets of material or immaterial nature. Whether or not the individual will exercise control over the co-operative depends on the extent to which the member's need for place is active.

\section{Stimulation}

Several scholars (e.g., Duncan, 1981; Porteous, 1976) have suggested ownership serves yet another human need: the need for stimulation (activation, arousal). Kamptner (1989), when commenting upon the psychological meaning of possessions, noted that the targets of ownership serve as 'the storehouses of life's meanings.' The works of Jussila et al. (2007) and Tuominen et al. (2006) from the co-operative context seem to indicate that consumer co-operatives can occupy such roles.

Thus, from an emotional perspective, consumers' co-operative societies provide entertainment to their members in terms of their being repositories holding memories of the past. Interacting with elements of the co-operative organization that serve as 'memory triggers' needing to be taken care of, serves as a source of stimulation for the member. Stimulation can be derived, for example, from one's using, thinking about, improving, observing, caring, and defending one's possessions (e.g., Kamptner, 1989; Duncan, 1981; Porteous, 1976).

Thus, considering that use in the core of cooperation, it seems obvious that also the need for stimulation can be served by co-operative membership. When using the co-operative, one cannot avoid observing it and thinking about it. There is also an incentive for the members to care for and improve their co-operative (Mills, 2008). Engagement in thoughts and (other) actions of caring and improving will provide the member with stimulation. As Jussila et al.'s (2007) work suggests, members are also known defend their co-operatives - the storehouses of the communities' local meanings - and, thus, be aroused by them. In this context, feelings of ownership are likely to develop and be maintained through traveling the routes described above. As preceding discussion suggests, the routes to psychological ownership can be traveled in many ways, in different roles, and to many destinations material and immaterial in nature. Whether or 


\section{Exploring the Consumer Co-Operative Relationship with Their Members: An Individual Psychological Perspective on Ownership}

not the individual will exercise control over the co-operative depends on the extent to which the member's need for stimulation is active.

\section{CONCLUSION}

The content of 'the co-operative link' (Giroux, 1992) and 'the strong linkage' (Normark, 1996) is, to great extent, psychological ownership.A clearly defined individual-level cognitive/affective state can be measured with the instrument validated by Van Dyne and Pierce (2004). In other words, when investigating the depth of a member's relationship with the cooperative, the construct of psychological ownership and the existing measure for it are extremely useful.

In research on consumer co-operatives, the psychological state of ownership has been previously referred to in the work of Jussila et al. (2007) and Tuominen et al. (2006). We went beyond their work to analyzing in detail the mechanisms through which psychological ownership emerges. We believe that addressing the role of control, knowledge, and self-investment in the development of the well-recognized strong linkage (psychological ownership) between the member and the co-operative adds value to cooperative research. Especially valuable we consider our work to be for researchers of co-operative management, since that special relationship manifested by psychological ownership is seen as a source of psychological rewards for the members and, thus, competitive advantage for the co-operatives (Jussila et al., 2008).

It is well known among co-operative researchers that the motives for membership are not limited to economic utility, even if it is often seen as the primary reason for establishing co-operatives. In this paper we have addressed the roles of several human needs that can also be seen as important reasons for participating in co-operative projects. Efficacy and effectance motivation as well as the needs for self-identity, place, and stimulation contribute to our understanding as to why consumers are willing to participate in cooperation both as users and as owners. It is expected satisfaction of these motives (pleasure) that facilitates the interaction leading to psychological ownership.

\section{Managerial Implications}

It is not only the uncovering of the consumer - cooperative - relationship and pointing out a useful measure that we believe to be of practical value. Our specification and analysis of the routes to psychological ownership will help co-operative managers reinforce of the co-operative link and, thus, contribute to their organizations' favorable position in the market place. Noteworthy, this can be seen to be in line with the purpose of consumer co-operatives, when managerial action of this sort is aimed at creating additional value to the customer-owner that is not attempted to materialize in price increases. What can managers to develop a stronger and more intimate link between the consumers and their cooperatives - one that is manifested with feelings of ownership and a sense of being one with the cooperative? 


\section{Exploring the Consumer Co-Operative Relationship with Their Members: An Individual Psychological Perspective on Ownership}

Our work suggests that this can be achieved by promoting the consumers' opportunities to interact and associate with the co-operative. Developing new ways of influence and control, providing the members with efficient ways to come to know the qualitative properties of cooperatives, and introducing additional ways and forums for members to investment their energies, intellect, and knowhow into the co-operative serve to increase the potential for the development of psychological ownership among members. However, it seems that the members' role as owners and the potential ways of participation need to also be communicated well. Psychological ownership will not develop if the members do not realize their status. Further, considering that the expectation of satisfaction is central to the motives, it seems that stories of highly satisfied active members could help eliminate some of the passiveness and promote member interaction with the co-operatives.

\section{Future Research}

As introduced, a detailed discussion of the whole variety of consequences that are seen as an outgrowth of psychological ownership is something that needs to be done in the future. The work of Pierce et al. (2009) among others specifies a variety of attitudinal consequences of psychological ownership in addition to satisfaction. These include, for example, organizational commitment and a sense of responsibility. That work addresses also behavioral effects such as extra-role behavior, taking personal risks, and making personal sacrifices (to the benefit of the target of ownership). We believe that the employment of the effects - side of the psychological ownership theory in the analysis of consumer - cooperative - relationships would benefit cooperative scholarship and practice. Theoretical work address in the connections between psychological ownership and the attitudes and behaviors identified as being manifested in cooperatives is an alternative.

Considering that the effects may be mixed and more contextual factors must be taken into account, a case study taking cognize of the full variety of dynamics associated with the psychological state might be more appropriate. However, a quantitative survey is not thinkable option either, since (to our knowledge) many elements of the homological network already have established measures.

Finally, on the more abstract level, much of what is put forward above applies not only to consumer cooperatives, but to other types of co-operatives as well. However, given that cooperatives are different in terms of who owns them and, thus, in their operation and purpose, we would like to offer a word of caution. Considering the potential of co-operatives as satisfiers of the above mentioned motives, it is likely not to be the same across consumers' and workers' cooperatives and those co-operatives that at best reflective of multiparty alliances of entrepreneurs. Probably the relative 'weight of' objective and subjective elements of (motives for) ownership is likely to be vary across these types. We also assume that context will make a 


\section{Exploring the Consumer Co-Operative Relationship with Their Members: An Individual Psychological Perspective on Ownership}

difference in particular when analyzing the consequences of psychological ownership and the dynamics associated with them in these different types of co-operatives. Of course, future research can prove our assumptions wrong.

\section{Acknowledgments}

The author appreciates all those who participated in the study and helped to facilitate the research process.

Conflict of Interests: The author declared no conflict of interests.

\section{REFERENCES}

For Journals

Bager, T. (1994) Isomorphic processes and the transformation of co-operatives.Annals of Public and cooperative Economics, 65(1):35-59

Beggan, J. K. (1991) Using what you own to get what you need: The role of possessions in satisfying control motivation. Journal of Social Behavior and Personality, 6 (Special Issue): $129-146$.

Beggan, J. K., \& Brown, E. M. (1994) Association as a psychological justification for ownership. Journal of Psychology. 128: 365-380.

Belk, R. W. (1988) Possessions and the extended self. Journal of Consumer Research, 15(2): 139-168.

Casadesus-Masanell, R. \& Khanna, T. (2003) Globalization and Trust: Theory and Evidence from co-operatives. William Davidson Institute Working Paper No.592

Chaves, R. Soler, F. \&Sajardo, A. (2008) Co-operative Governance: the case of Spanish Credit Co-operatives. Journal of Co-operative Studies, 41(2): 30 - 37

Cook, M. L. (1994) The Role of Management Behavior in Agricultural co-operatives. Journal of Agricultural Cooperation, 9: 42-58.

Cram, F., \& Paton, H. (1993) Personal possessions and self-identity: The experiences of elderly women in three residential settings. Australian journal on Aging, 12(1): 19-24.

Fasig, L. (2000). Toddlers Understanding of Ownership: Implications for Self-Concept Development. Social Development, 9(3): 370-382

Furby, L. (1978b) Possession in humans: An exploratory study of its meaning and motivation. Social Behavior and Personality, 6(1): 49-65.

Furby, L. (1980) The origins and early development of possessive behavior. Political Psychology.2: 30-42.

Giroux, Henry A. (1992) Participation in Strategic Decisionmaking in a co-operative. Annals of Public and Co-operative Economics, 63(1), 5-24.

Jussila, I. (2007). Ownership in Customer-owned Cooperatives (a Doctoral Dissertation in Finnish). Acta Universitatis Lappeenrantaensis, 271. 


\section{Exploring the Consumer Co-Operative Relationship with Their Members: An Individual Psychological Perspective on Ownership}

Jussila, I., Saksa, J-M., \& Tienari, J. (2007) Dynamics and Tensions in Governance: evidence from Finnish cooperatives. International Journal of Co-operative Management, 3(2): 29 - 39

Jussila, I., Tuominen, P., \& Saksa, J.M. (2008) Following a different mission: where and how do consumer co-operatives compete? Journal of Co-operative Studies, 41(3), 28-39.

Klein, K. J. (1987) Employee Stock Ownership and Employee Attitudes: A Test of Three Models. Journal of Applied Psychology, 72(2): 319-332

Kline, L., \& France, C. 1. (1899) The psychology of mine. Pedagogical Seminary \& Genetic Psychology, 6: 421-470.

Long, R. J. (1979) Desires for and patterns of worker participation in decision making after conversion to employee ownership. Academy of Management Journal, 22(3):611-617

Long, R. J. (1980) Job Attitudes and Organizational Performance Under Employee Ownership. Academy of Management Journal, 23(4): 726-737

Mills, C. (2008) Do Large Membership-Based Businesses have a Future in the Twenty First Century? Some reflections on UK retail co-operative societies. Journal of Co-operative Studies, 41(2): 17-29.

Nilsson, J. (1996) The nature of co-operative values and principles - Transaction cost theoretical explanations. Annals of Public and co-operative Economics, 67(4):633-653.

Normark, P. (1996) A Role for Co-operatives in the Market Economy. Annals of Public and Cooperative Economics, 67(3): 429-439.

Pierce J. L.; O Driscoll, M. P. \& Coghlan, A-M. (2004) The Psychology of Possessions: Work Environment Structure, Organizational Commitment and Citizenship Behaviors. The Journal of Social Psychology, 144:507-534

Pierce, J. L., \& Rodgers, L. (2004) The psychology of Ownership and Worker-Owner Productivity. Group and Organization Management, 29(5): 588-613

Pierce, J. L., \&Furo, C. A. (1990) Employee Ownership: Implications for Management. Organizational Dynamics, 18: 32-43

Pierce, J. L., Jussila, I., \& Cummings, A. (2009) Psychological Ownership within the Job Design Context: Revision of the Job Characteristics Model. Journal of Organizational Behavior, 30(4), 477-496.

Pierce, J. L., Rubenfeld, S. A., \& Morgan, S. (1991) Employee ownership: A conceptual model of process and effects. Academy of Management Review, 16(1): 121-144.

Pierce, J. L.; Kostova, T., Dirks, K. T. (2001) Toward A Theory of Psychological Ownership in Organizations. Academy of Management Review, 26(2): 298-310

Pierce, J. L.; Kostova, T., Dirks, K.T. (2003) The State of Psychological Ownership: Integrating and Extending a Century of Research. Review of General Psychology. 7(1): 84- 107

Porteous, J. D. (1976) Home: The territorial core. Geographical Review, 66:383-390.

Prelinger, E. (1959) Extension and structure of the self. The Journal of Psychology, 47: 13-23.

Rousseau, D. M. \& Shperling, Z.(2003) Pieces of the Action: Ownership and the Changing Employment Relationship. Academy of Management Review, 28(4):553-570

(C) The International Journal of Indian Psychology, ISSN 2348-5396 (e)| ISSN: 2349-3429 (p) | 135 


\section{Exploring the Consumer Co-Operative Relationship with Their Members: An Individual Psychological Perspective on Ownership}

Rudmin, F. W., \& Berry, J. W. (1987) Semantics of ownership: A free-recall study of property. The Psychological Record, 37: 257-268.

Spear, R. (2004) Governance in democratic member-based organisations. Annals of Public and co-operative Economics, 71(1): 33-59.

Tuominen, P., Jussila, I., \& Kojonen, S. (2009) Overcoming challenges to governance of consumer co-operation: Analysing reports of key representatives. International Journal of Co-operative Management, 4(2), 22-35.

Tuominen, P., Jussila, I., \& Saksa, J-M. (2006) Locality and Regionality in Management of Finnish Customer Owned Co-operatives. International Journal of Co-operative Management, 3(1): 9-19.

Van Dyne, L. \& Pierce, Jon L. (2004) Psychological Ownership and Feelings of Possession: Three Field Studies Predicting Employee Attitudes and Organizational Behavior. Journal of Organizational Behavior, 25: 439-460

Vandewalle, D., Van Dyne, L., \& Kostova, T. (1995) Psychological ownership: An empirical examination of its consequences. Group and Organization Management, 20(2): 210-226.

Wagner, S. H., Parker, C.P. \& Christiansen, N. D. (2003) Employees that think and act like owners: effects of ownership beliefs and behaviors on organizational effectiveness. Personnel Psychology. 56(4):847-871

White, R. W. (1959) Motivation reconsidered: The concept of competence. Psychological Review, 66: 297-330. Miscellaneous

\section{For Books}

Ardrey, R. (1966) The territorial imperative: A personal inquiry into the animal origins of property and nations. New York: Dells.

Beaglehole, E. (1932) Property. A study in social-psychology. New York: Macmillan. Csikszentmihalyi, M.

Dirks, K. T., Cummings, L. L., \& Pierce, J. L. (1996) Psychological ownership in organizations: Conditions under which individuals promote and resist change. In R. W. Woodman \& W. A. Pasmore (Eds.), Research in organizational change and development, 9: 1-23. Greenwich, CT: JAI Press.

Dittmar, H. (1992) The social psychology of material possessions: To have is to be. New York: St. Martin's Press.

Dreyfus, H. L. (1991) Being-in-the-world: A Commentary on Heidegger's being and time. Cambridge, MA: MIT Press.

Duncan, N. G. (1981) Home ownership and social theory. In 1. S. Duncan (Ed.), Housing and identity: Cross-cultural perspectives: 98-134. London: Croom Helm.

Furby, L. (1978a) Possessions: Toward a theory of their meaning and function throughout the life cycle. In P. B. Baltes (Ed.), Life span development and behavior, 1: 297- 336. New York: Academic Press.

(c) The International Journal of Indian Psychology, ISSN 2348-5396 (e)| ISSN: 2349-3429 (p) | 136 


\section{Exploring the Consumer Co-Operative Relationship with Their Members: An Individual Psychological Perspective on Ownership}

Hansmann, H. (1996) The Ownership of Enterprise. London: The Belknap Press of Harvard University Press.

Heidegger, M. (1967) Being and time. (Translated by J. Macquarrie \& E. Robinson.) Oxford: Blackwell.

Kamptner, N.L. (1989) Personal possessions and their meanings in old age. In: Spacapan, S. and Oskamp, S., (Eds), The social psychology of aging, Sage Publications, Newbury Park, CA, pp. 165-196.

Münkner, H. (1981) Co-operative Principles and Co-operative Law. 4th reprint. Marburg/Lahn: Institute for Cooperation in Developing Countries.

Patel, A, (2012), “MIND POWER”, Shabdlok Prakashan, Ahmedabad, ISBN: 9789381357361, Page: 25 to 30

Rochberg-Halton, E. (1981) The meaning of things: Domestic symbols and the self. Cambridge: Cambridge University Press.

Rudmin (Ed.), To have possessions: A handbook on ownership and property. Special Issue, Journal of Social Behavior and Personality, 6: 465-468.

Sartre, J. P. (1969) (First published in 1943.) Being and nothingness: A phenomenological essay on ontology. New York: Philosophical Library.

Tannenbaum, A. S. (1983) Employee-owned companies. In L. L. Cummings \& B. M. Staw (Eds.), Research in organizational behavior, 225-268. Greenwich, CT: JAI.

Weil, S. (1952) The need for roots: Prelude to a declaration of duties towards mankind. London: Routledge and Kegan Paul Ltd.

How to cite this article: Singh S (2017), Exploring the Consumer Co-Operative Relationship with Their Members: An Individual Psychological Perspective on Ownership, International Journal of Indian Psychology, Volume 4, Issue 2, No. 88, ISSN:2348-5396 (e), ISSN:2349-3429 (p), DIP:18.01.074/20170402, ISBN:978-1-365-74161-6 